\title{
Aktør eller brikke?
}

\author{
Omorganiseringen i norsk helsetjeneste er en kontinuerlig prosess som noen \\ arbeidstakere mestrer bedre enn andre.
}

D en enkelte arbeidstaker og de ulike profesjonene opplever omorganiseringer svært forskjellig. Store omorganiseringer kan medføre at både den individuelle og profesjonsmessige selvforståelsen justeres og endres. Mestringsstrategiene våre varierer og påvirkes blant annet av om vi ser på oss selv som en aktør eller en brikke i vårt eget liv. Denne artikkelen er basert på en undersøkelse jeg gjorde i hovedfag i pedagogikk i forbindelse med at sykehusreformen ble implementert. Jeg ønsket å få større innsikt i: Hvordan sykepleielederes handlinger og valg av mestringsstrategier i en gitt omstillingsprosess er uttrykk for den enkelte leders selvforståelse.

\section{Lovendring}

I en av de fire helselovene, Spesialisthelsetjenesteloven § 3-9, heter det at: «Sykehusene skal organiseres slik at det er en ansvarlig leder på alle nivåer. Departementet kan i forskrift kreve at lederen skal ha bestemte kvalifikasjoner. Dersom kravet til forsvarlighet gjør det nødvendig, skal det pekes ut medisinsk faglig rådgiver» $(1$, s. 40).

\section{Hovedbudskap}

Temaet for denne artikkelen er hvordan lederes selvforståelse påvirker mestringsstrategier og læring gjennom erfaring i en konkret omorganisering. Hvordan ledere forholder seg til store organisatoriske endringer som også innebærer individuelle konsekvenser ved at det påvirker deres stilling og ansettelsesforhold.

\section{Nøkkelord}

Les mer og finn litteraturhenvisninger på våre nettsider. > Mestring /Omorganisering /Organisering
For første gang fikk vi et lovverk som åpner opp for at sykepleiere og andre helseprofesjoner kan fungere i lederjobber som medisinsk ansvarlige.

\section{Selvforståelse}

Jeg valgte å fokusere på selvforståelse slik Nygaard (2) beskriver fenomenet. Nygaard sier at noen mennesker ser på seg selv som aktører; frie, handlende mennesker, mens andre er tilbøyelige til å se på seg selv som brikker; ofre for krefter de ikke har noe innflytelse over. De fleste personer befinner seg på en skala hvor man er mer brikke enn aktør eller mer aktør enn brikke, ofte påvirket av den konteksten man står i. Nygaard (2) sier videre at for å forstå hvordan vi forholder oss til de forskjellige situasjonene vi kommer opp i, er vår selvforståelse sentral. Vår selvforståelse er ikke naturgitt, men resultatet av en konstruksjonsprosess, som i sin tur får betydning for hvor vi havner på skalaen fra brikke til aktør.

\section{Mestring}

Videre har jeg sett på mestring i lys av Antonovskys (3) teori om salutogenese. Begrepet er hentet fra latin og betyr tilblivelse av helse. Antonovsky mener at opplevelsen av sammenheng, som handler om menneskets evne til å forstå, håndtere og finne mening i situasjonen, ligger til grunn for og påvirker våre valg av mestringsstrategier (4).

\section{Kriterier}

Jeg har ønsket å beskrive og tolke hvordan informantenes selvforståelse kom til uttrykk gjennom deres tanker, følelser og handlinger. For å oppnå dette har jeg benyttet en kvalitativ tilnærming (5) og intervjuet syv mellomlederes fortellinger og refleksjoner. Fortellingene strekker seg over en periode på cirka ett år, som var tiden omorganiseringen ved sykehuset tok. Undersøkelsen ble gjort etter at ansettelsesprosessen var over. Intervjuene ble gjort i en periode på 14 dager, og de ble tatt opp på bånd.

\section{Etisk aspekt}

Det ble gitt skriftlig informasjon om prosjektet samt innhentet informert samtykke fra de syv informantene. Materialet ble behandlet konfidensielt og slettet etter at undersøkelsen var avsluttet. Deltakerne arbeidet på hver sin avdeling, men hadde felles møter. Alle data er anonymisert.

\section{Resultater}

Informantenes selvforståelse ble sett på i forhold til:

> Informasjon som ble gitt

\ Handlingsvalg den enkelte informant gjorde , Informantenes egne tanker og følelser

\section{Informasjon}

I starten av omorganiseringen ble det gitt felles informasjon til alle lederne om at sykehuset, ut fra politiske føringer og vedtak, skulle implementere lovendringer som medførte forandringer i lederstrukturen på mellomledernivå. Konsekvensene ville medføre store endringer for den enkelte mellomleder. Informantene reagerte forskjellig på informasjonen. Enkelte var rolige og avventende, mens andre ble redde, triste, sinte og urolige. Andre opplevde at informasjonen de fikk var dårlig.

Ifølge Nygaard er det ikke ytre faktorer som bestemmer vår reaksjon i en slik situasjon (2). Vi tolker eller konstruerer noe ut ifra de ordene som blir sagt. Hvordan vi forholder oss til den situasjonene vi kommer opp i er ikke naturgitt, 


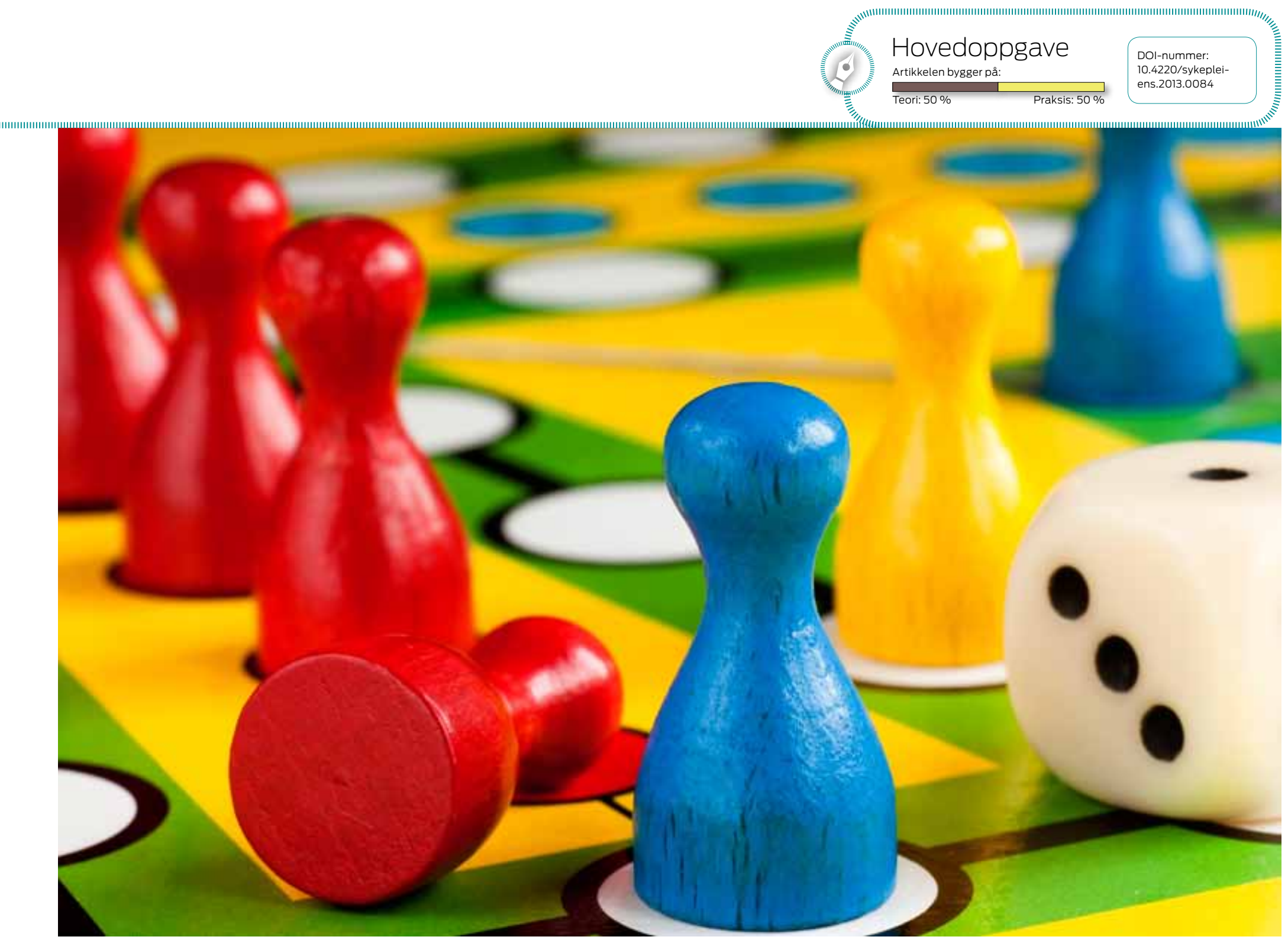

SLETT SPILL: Noen arbeidstakere inntar rollen som aktive aktører når det omorganiseres på arbeidsplassen, mens andre blir passive brikker. Illustrasjonsfoto: Colourbox

men handler om hvilken mening vi legger i situasjonen og det som blir sagt (3). Den meningen sykepleielederne la i det som ble sagt og situasjonen rundt informasjonen, altså de ytre realitetene, ble avgjørende for deres reaksjon og handlemåte. Derfor ble også reaksjonene forskjellige.

Informantene uttrykte at manglende informasjon ble en følelsesmessig belastning og stressfaktor. Det å ikke helt vite hva som skulle skje skapte utrygghet. De beskrev en høy aktivitet blant lederne sine, men uten at de fikk tilgang på informasjon. Det er viktig å forstå den situasjonen man er i, og at man har evnen til å strukturere de begivenhetene som skjer, slik at kaos ikke oppstår (3). For å forstå prosessen trenger man blant annet informasjon og den informasjonen informantene trengte uteble.

\section{Handlingsvalg}

I det vakuumet av manglende informasjon som oppsto søkte informantene etter hvert sammen. De begynte å utvikle en felles strategi, noe de ikke hadde gjort tidligere. De ønsket å ha et forum eller møtepunkt hvor de kunne styrke hverandre og stå sammen i situasjonen som de opplevde som problematisk. Den som lever sitt liv som aktør, beholder en viss grad av frihet til å velge, mens den som ser på seg selv som brikke i spillet, langt på vei har tapt friheten til å velge og handle (2). Som gruppe inntok informantene aktørrollen. De presset på oppover i systemet for å få informasjon og være i dialog med ledelsen. Her viste de seg som handlende mennesker som ønsket å påvirke situasjonen, og unngikk dermed å bli redusert til brikker i et spill der spillereglene var bestemt av andre. De valgte aktivt, tok ansvar, handlet og opptrådte med høy selvstendighet i situasjonen. Komponentene meningsfullhet og håndterbarhet var viktige for den grad av mestring sykepleielederne viste på dette tidspunktet (3).

I denne fasen ble det ikke fokusert så mye på det enkelte individ. Informantene tenkte og opptrådte mer kollektivt. Den enkeltes selvforståelse ble ikke så tydelig profilert. Men når søknadsfristen for den nye stillingen nærmet seg, beveget informantenes oppmerksomhet seg fra det kollektive til det individuelle.

\section{Egne tanker og følelser}

Etter at stillingen var utlyst reflekterte infor- mantene over om de skulle søke lederjobben eller ikke. I disse overveielsene kom den individuelle selvforståelsen tydeligere fram. De fokuserte på i hvilken grad de så på seg selv som kvalifiserte eller ikke til jobben. En som ikke søkte uttrykte at hun var blitt for gammel og trodde ikke at hun var rett person til den nye stillingen. Hun ville ikke ødelegge helsen

\section{«Manglende informasjon ble en følelsesmessig belastning og stressfaktor.»}

sin i en krevende jobb. Dette er uttrykk for en aktørholdning og kan betraktes som en realistisk virkelighetsforståelse basert på vurdering av egen kapasitet og helse.

Den andre som ikke søkte mente hun ikke hadde noe reelt valg. Stillingen var av tidligere direktør «gitt bort» til en lege. Hun mente at hun var kvalifisert til stillingen, men trodde det ville bli mye konflikter og «fighting», og kom til at hun heller ville gjøre noe annet. Dette er uttrykk for at personen nedtoner verdien av 
stillingen for seg selv, men samtidig åpner for at hun kan være rett person til å klare en slik jobb. Men alt dette blir hypotetisk i og med at stillingen allerede var "gitt bort», og hun ble gjort til en brikke i et system.

\section{Trygghet}

Tre av informantene som søkte stillingen, men som ikke fikk den, vektla at de hadde erfaring som ledere og hadde mestret de oppgavene det medførte tidligere. Denne oppfatningen av egen mestring økte forventningene om å klare tilsvarende oppgaver, og det ga dem en trygghet og tro på at de ville klare denne jobben. Slike mestringserfaringer er med å styrke selvtilliten

\section{«Legene kjørte beinhardt på at det var uansvarlig å ha en sykepleier som leder.»l}

og selvforståelsen. Skaalvik og Skaalvik (6) skiller mellom to aspekter ved mestringserfaringer: Reell mestring og opplevd mestring. Den reelle mestringen er «objektiv» på den måten at den er opplevd og registrert av omgivelsene. Opplevd mestring er subjektiv og dreier seg om den enkeltes egen opplevelse av mestring. Informantene uttrykte en subjektiv opplevd mestring i forhold til egen vurdering av seg selv som leder. Andres vurdering av dem som leder sa de ikke noe om.

\section{Motstand}

Den tredje lederen som ikke fikk stillingen, uttrykte at hun visste at hun hadde gode lederegenskaper, og at hun var på høyde med dem hun skulle konkurrere med. Hun opplevde at motstanden i ledergruppa var enorm. Legene kjørte beinhardt på med brev til Legeforeningen og sykehusledelsen om at det var uansvarlig å ha en sykepleier som leder. Dette skjedde selv om lederen hadde formelt og erfaringsmessig mer kompetanse enn de andre aktuelle lederne.

Informanten hadde en klar erkjennelse av at hun var best kvalifisert, både formelt og erfaringsmessig. Hun opplevde den aktive motstanden fra legene som vanskelig, noe som medførte at hun valgte en mer avventende holdning for å beskytte seg mot motstanden, og handlet som en aktør. Hun registrerte at det foregikk en stor aktivitet rundt henne blant legene, uten at noe ble sagt til henne. Dette ga henne perioder med uro og hadde en handlingslammende effekt. Uro for om det ville bli for tøft å være leder for en gruppe som mente det var helt galt om hun ble leder. Hun gjorde en realistisk vurdering ut fra virkeligheten hun sto $\mathrm{i}$, men bestemte seg for å stå løpet ut og beveget seg på skalaen mellom aktør og brikke.

\section{Høy motivasjon}

Hos de to som fikk stillingen var bevisstheten og vurderingen av om de fikk stillingen noe forskjellig. Den ene var klar på at denne lederstillingen ville hun ha. Hun var tydelig på at hvis hun ikke fikk stillingen, så kom hun til å slutte. Hun sa tydelig at hun så på seg selv som best kvalifisert. Hun ble truet mange ganger, hvor det ble sagt at det ville bli hett for henne, for legene vil ikke finne seg i en sykepleier som leder.

Denne informanten beskriver seg som en leder med høy motivasjon. Hun hadde erfaringer og en tydelig selvforståelse knyttet til hvem hun er som person. Hun fremsto som en person med høy selvtillit tross motstand, blant annet i form av trusler. Hun viste ingen emosjonelle reaksjoner på truslene hun fikk. Det kan nesten virke som om hun fikk en sterkere motivasjon og vilje til å kjempe for stillingen av dette. Informanten viste en tydelig aktørholdning. Hun synliggjorde både for seg selv og andre at hun så på seg selv som den beste søkeren.

Den andre som fikk stillingen vektla sine ferdigheter og virket trygg. Men selv om hun hadde både formal- og erfaringskompetanse som leder, tvilte hun på om ledelsen våget å trosse legenes motstand. Informantene hadde på et tidligere stadium i prosessen vært opptatt av å stå sammen. De hadde utviklet en felles profesjonsforståelse. I fasen rundt stillingssøknaden ble denne holdningen redusert, og informantene så seg selv i lys av motkandidaten. Den enkeltes posisjon og framtid var nå det viktigste.

\section{Diskusjon}

Utgangspunkt for denne undersøkelsen var å få innsikt i hvordan avdelingsoversykepleiernes handlinger og valg av mestringsstrategier i en gitt omstillingsprosess var uttrykk for den enkelte leders selvforståelse. Dette ble sett på i lys av informasjonen som ble gitt i prosessen, handlingsvalg som den enkelte informant gjorde og informantenes egne tanker og følelser rundt den nye stillingen.

Informantene hadde en felles forståelse av reformen i den forstand at de anerkjente at de som sykepleieledere kunne inneha den nye stillingen. Dette ga dem i perioder, når de sto sammen, mot til å kreve den informasjonen de hadde krav på uten at det ble innfridd.

Samtidig opplevde de informasjonen som minimal, nesten fraværende, og det gjorde at enkelte ble resignerte mens andre ble sinte. Selvforståelsen påvirker oppfatningen og tolkningen av informasjonen som ble gitt. Samtidig kan man anta at mangelen på informasjon var med på å bidra til enten å styrke, svekke eller endre mottakerens selvforståelse på skalaen mellom aktør og brikke. På den andre siden kan det virke som om reformens positive intensjon med en profesjonsnøytral ledelse påvirket informantenes handlingsfrihet i mindre grad. De fokuserte mer på legenes utsagn om at de ikke ville akseptere en sykepleier som leder. Dette perspektivet ble en stressfaktor som i større eller mindre grad pasifiserte sykepleielederne og svekket selvforståelsen hos de fleste, samt troen på at de hadde en reell sjanse til å få stillingen. Man kan anta at disse tankene svekket handlingsfriheten og mestringsopplevelsen, som igjen medførte at de beveget seg mot en brikkeposisjon.

\section{Konklusjon}

Informantene delte sin fortelling etter at ansettelsesprosessen var ferdig, og bekreftet at ved å dele sine fortellinger satte de i gang en tankeprosess og en bevisstgjøring som hjalp dem til å forstå hva som kan ligge til grunn for de håndteringsstrategiene de valgte i prosessen de har vært igjennom. Ved å dvele ved konsekvensene av sine erfaringer og sette dem i forbindelse med selve handlingen, er det sannsynlig at informantene utviklet et refleksjonsgrunnlag for lignende situasjoner i framtiden. Slik kan vi anta at læring på bakgrunn av refleksjon over erfaringer fant sted. IIII

\footnotetext{
REFERANSER:
1. Helse- og Omsorgsdepartementet - Lov om spesialisthelsetjenesten (spesialisthelsetjenesten) 2001. Tilgjengelig 15.10.2002: http://www.lovdata.no Nygård R. Aktør eller brikke. Oslo: Cappelens Forlag AS, 2007.

3. Antonovsky A. Helsans mysterium. Stockholm: Natur och kultur, 1991 . Antonovsky A. Helsans mysterium. Stockholm: Natur och kultur, 1991. Antonovsky A. Unravelling the Mystery of Health. How peop.
stress and stay well. San Francisco: Jossey-Bass Publ., 1987. stress and stay well. San Francisco: Jossey-Bass Publ., 1987. . Kvale S. Det kvalitative forskningsintervju. Oslo: Ad Notam Gyldendal, 2001. Skaalvik S, Skaalvik E. Selvoppfatning, motivasjon og læringsmiljø. Oslo: Tano Aschoug, 1998
}

Fagartikler kan sendes til torhild.apall@sykepleien.no 